\title{
AGRONOMIC PERFORMANCE OF IRRIGATED CROP ROTATIONS UNDER CONVENTIONAL AND NO-TILLAGE SYSTEMS IN THE SEMIARID REGION OF MINAS GERAIS, BRAZIL ${ }^{1}$
}

\author{
JOÃO VÍCTOR SANTOS GUERRA ${ }^{2 *}$, ABNER JOSÉ DE CARVALHO², ARLEY FIGUEIREDO PORTUGAL ${ }^{3}$, \\ IGNACIO ASPIAZÚ2 ${ }^{2}$, MARCOS KOITI KONDO ${ }^{2}$, SILVÂNIO RODRIGUES DOS SANTOS ${ }^{2}$
}

\begin{abstract}
The objective of this work was to evaluate the agronomic performance and water use efficiency of crop rotations under conventional system (CTS) and no-tillage system (NTS) through two experiments conducted in the Semiarid region of the northern state of Minas Gerais, Brazil. Experiment 1 consisted of a grain corn-common bean rotation, and experiment 2 consisted of a sorghum-sweet corn rotation. The treatments, in both experiments, consisted of two tillage systems (CTS and NTS) arranged in strip-plots, in two crop years, with ten replications. Yield and production components of all crops and water use efficiency (WUE) of crops grown in the autumn-winter seasons were evaluated within each crop rotation. The data obtained were subjected to analysis of variance and, when significant, the means were subjected to the F test at $5 \%$ significance level. The results obtained showed that the NTS increases corn yield in $21.45 \%$ in the grain corn-common bean rotation; however, the common bean yield present no difference between tillage systems. NTS increases the sorghum fresh and dry matter yields in $39.65 \%$ and $84.26 \%$, respectively, in the sorghumsweet corn rotation, and the sweet corn total and commercial ear yield in $11.99 \%$ and $21.80 \%$, respectively. The NTS increases the WUE of crops grown in the autumn-winter season, in both crop rotations.
\end{abstract}

Keywords: Yield. Water use efficiency. No-tillage. Northern Minas Gerais.

\section{DESEMPENHO AGRONÔMICO DE SUCESSÕES DE CULTURAS IRRIGADAS SOB PLANTIO DIRETO E CONVENCIONAL NO SEMIÁRIDO MINEIRO}

\begin{abstract}
RESUMO - Objetivou-se com esse trabalho avaliar o desempenho agronômico e a eficiência do uso da água de sistemas de sucessão de culturas em preparo convencional (PC) e plantio direto (PD), em dois experimentos instalados na região norte de Minas Gerais. O experimento 1 foi constituído pelo plantio em sucessão de milhogrão / feijão-comum, e o experimento 2 constituído pelo plantio em sucessão de sorgo / milho-verde. Em ambos os experimentos, os tratamentos foram constituídos por dois sistemas de manejo (PC e PD), dispostos no esquema de faixas, em dois anos de cultivo, com dez repetições. Foram avaliadas a produtividade e os componentes de produção de cada cultura, além da eficiência no uso de água (EUA) pelas culturas instaladas nas safras de outono-inverno, dentro de cada sistema de sucessão. Os dados obtidos foram submetidos à análise de variância, e, no caso de significância, as médias foram estudadas pelo próprio teste $\mathrm{F}$ a $5 \%$ de significância. Os resultados obtidos permitiram concluir que na sucessão milho-grão / feijão-comum, o PD aumenta a produtividade do milho em $21.45 \%$, contudo, não há diferença entre os manejos para a produtividade feijãocomum. Na sucessão sorgo / milho-verde, o PD proporciona aumento da produtividade da matéria verde e matéria seca de sorgo em 39.65 e $84.26 \%$, respectivamente, enquanto que no cultivo do milho-verde, o PD aumenta em 11.99 e $21.80 \%$, respectivamente, a produtividade de espigas totais e comerciais. Nos dois sistemas de sucessão, o PD proporciona aumento na EUA pelas culturas, nas safras de outono-inverno.
\end{abstract}

Palavras-chave: Produtividade. Eficiência no uso da água. Semeadura direta. Norte de Minas Gerais.

\footnotetext{
${ }^{*}$ Corresponding author

${ }^{1}$ Received for publication in 07/02/2020; accepted in 07/26/2021.

Paper extracted from the first author's master's thesis.

${ }^{2}$ Department of Agricultural Sciences, Universidade Estadual de Montes Claros, Janaúba, MG, Brazil; joaoifnmg@yahoo.com.br - ORCID: 0000-0002-9719-1602, abjocar@yahoo.com.br - ORCID: 0000-0002-6644-5307, aspiazu@gmail.com - ORCID: 0000-0002-0042-3324, marcoskondo@gmail.com - ORCID: 0000-0001-6875-4907, silvanio.santos@unimontes.br - ORCID: 0000-0003-0245-9184.

${ }^{3}$ Maize and Sorghum Unit, Empresa Brasileira de Pesquisa Agropecuária, Nova Porteirinha, MG, Brazil; arley.portugal@embrapa.br ORCID: 0000-0001-6056-3233.
} 


\section{INTRODUCTION}

Agriculture has a high socioeconomic importance in the North region of the state of Minas Gerais, Brazil, presenting a diverse profile composed of rainfed and irrigated areas with fruit, vegetable, and grain crops and pastures. However, despite the agricultural suitability of the region, it presents a semiarid climate characterized by a low and irregular rainfall regime with long drought periods and scarcity of water resources for irrigation, which has leading to underutilization and abandonment of crop areas (ALMEIDA et al., 2014). In this context, the use of tillage systems that favor soil and water conservation in these agroecosystems are essential to make agriculture feasible in the region.

Methods of soil management differ in extension, depth, and fragmentation level of the worked surface (GILLES et al., 2009). Therefore, similar soils under different tillage systems may present different degradation levels (SALES et al., 2016). These degradations are usually greater in areas under conventional tillage system (MARASCA et al., 2013).

The conventional tillage system is characterized by a complete soil turning in the whole area (GILLES et al., 2009) and presents advantages, such as removal of weeds, temporary increase of water infiltration, and incorporation of fertilizers (ALMEIDA, 2012). However, several studies have reported negative impacts for this method, mainly related to soil structure (PANACHUKI et al., 2011; MARASCA et al., 2013; SALES et al., 2016).

Some conservationist systems have been used to mitigate soil degradation problems in agricultural areas, mainly the no-tillage system, which is based on the exclusion or lowering of soil turning, maintenance of soil cover, and diversification of crops through crop rotation or intercropping (TIECHER et al., 2014).

Several studies have reported the benefits of no-tillage system, mainly increases in soil aggregation (SALES et al., 2016); control of erosion and nutrient losses (PUGLIESI et al., 2011); increases in crop yields (ROCHA et al., 2011; SILVA et al., 2015); and lowering of production costs (ALMEIDA et al., 2018). Moreover, in semiarid regions, the highest contributions of this system are the improvements in water storage in the soil surface layers (FIGUEIREDO; RAMOS; TOSTES, 2008), and water use efficiency (WUE) of plants (BIZARI et al., 2009; SILVA et al., 2015).

WUE refers to the total crop yield by quantity of water used throughout the crop cycle. Thus, higher WUE can be achieved when using strategies that increases yield and, mainly, when using techniques that decrease water losses (TEÓFILO et al., 2012). The maintenance of soil cover plants, one of the principles of the no-tillage system, stands out among techniques that favor water infiltration and decrease evaporation rates (PANACHUKI et al., 2011; MURGA-ORRILLO et al., 2016).

Despite the use of no-tillage system tends to contribute to the production of annual crops in semiarid regions, providing production gains and higher water use efficiency, few studies are conducted with this approach. Thus, the objective of this work was to evaluate the agronomic performance and WUE of corn-common bean and sorghum-sweet corn crop rotations under conventional (CTS) and no-tillage (NTS) systems in the Semiarid region of the northern state of Minas Gerais, Brazil.

\section{MATERIAL AND METHODS}

The experiments were conducted in the Experimental Field of the Embrapa Maize and Sorghum, in the Projeto Gorutuba, Nova Porteirinha, state of Minas Gerais, Brazil $\left(15^{\circ} 48^{\prime} 10^{\prime \prime} \mathrm{S}\right.$ and $43^{\circ}$ $18^{\prime} 03^{\prime \prime} \mathrm{W}$, and altitude of $\left.524 \mathrm{~m}\right)$. The region has an Aw climate, according to the Köppen classification, i.e., savanna climate with dry winter and mean air temperature in the coldest month above $18{ }^{\circ} \mathrm{C}$. The climate data collected during the experiment period are shown in Figure 1.

The soil of the experimental area was classified as a Typic Hapludox of mean texture (Latossolo Vermelho-Amarelo; SANTOS et al., 2013). The granulometric analysis of the soil showed $120 \mathrm{~g} \mathrm{~kg}^{-1}$ of coarse sand ( 2 to $0.2 \mathrm{~mm}$ ), $370 \mathrm{~g} \mathrm{~kg}^{-1}$ of fine sand $(0.2$ to $0.053 \mathrm{~mm}), 210 \mathrm{~g} \mathrm{~kg}^{-1}$ of silt, and $300 \mathrm{~g} \mathrm{~kg}^{-1}$ of clay in the $0.00-0.20 \mathrm{~m}$ layer; and $118 \mathrm{~g}$ $\mathrm{kg}^{-1}$ of coarse sand, $372 \mathrm{~g} \mathrm{~kg}^{-1}$ of fine sand, $215 \mathrm{~g} \mathrm{~kg}^{-}$ ${ }^{1}$ of silt, and $295 \mathrm{~g} \mathrm{~kg}^{-1}$ of clay in the $0.20-0.40 \mathrm{~m}$ layer.

The area had been cultivated with a cornsorghum rotation interspersed with fallow periods for 25 years before the implementation of the experiment; the area had been fallowed over the last 5 years prior to the experiment (2007 to 2012), presenting Panicum maximum L. as the predominant species.

Experiment 1 was conducted with grain corn in the spring-summer season and common bean in the autumn-winter season. Experiment 2 was conducted with forage sorghum in the springsummer season and sweet corn in the autumn-winter season. The crops of both experiments were conducted in conventional tillage (CTS) and notillage (NTS) system, which were the treatments evaluated in each experiment during two consecutive crop years. The NTS was carried out maintaining Brachiaria brizantha Hochst Stapf plants for soil cover between the spring-summer and autumnwinter seasons; $B$. brizantha seeds were sown together with the corn and sorghum seeds in the spring-summer seasons of Experiments 1 and 2, respectively. 


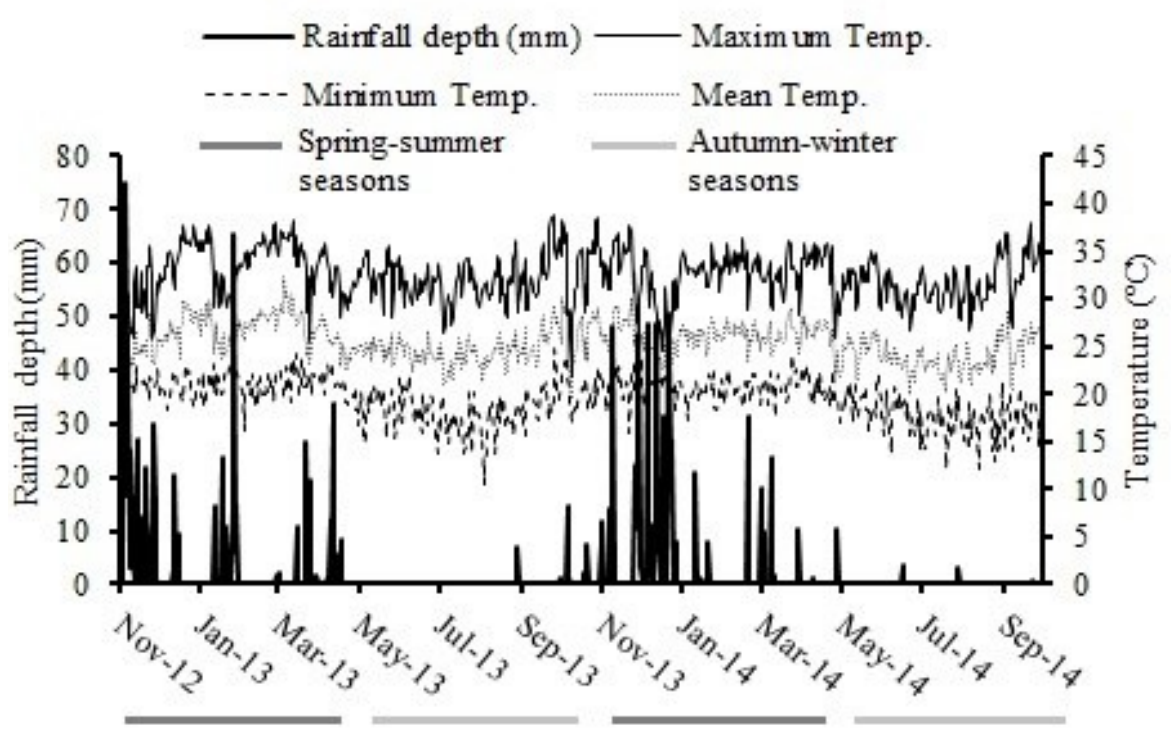

Figure 1. Rainfall depth $(\mathrm{mm})$ and maximum, mean, and minimum temperatures $\left({ }^{\circ} \mathrm{C}\right)$ during the conduction of the experiment. Nova Porteirinha, MG, Brazil. 2016. (Source: INMET, 2016).

Corn was grown using the simple hybrid BRS 1010 for both grain corn and sweet corn crops. The cultivar BRS Estilo was used for the common bean crops, and the variety BRS Ponta Negra was used for the forage sorghum crop.

The CTS consisted of soil preparation with one heavy harrowing and two light harrowing before the implementation of each crop. The NTS consisted of chemical desiccation of cover plants at the preplanting of each crop by applying the herbicide glyphosate at the rate of $5 \mathrm{~L} \mathrm{ha}^{-1}$, equivalent to 2400 g a.i. ha ${ }^{-1}$. The dry weight of the dead cover plants in the NTS was above $15 \mathrm{Mg} \mathrm{ha}^{-1}$. After the soil preparation, the planting was carried out for both tillage systems using a seeder-fertilizer equipped with cut discs that make possible the planting direct on the straw cover.

The treatments were arranged in strip-plots, with each tillage system (CTS or NTS) representing a strip, and carried out in two crop years, with ten replications. After the soil preparation according to the tillage systems for each treatment, the corn was planted in Experiment 1 and sorghum in Experiment 2 , both in the second half of November of 2012 and 2013, corresponding to the spring-summer seasons. In Experiment 1, the plots with corn consisted of four 4-meter rows spaced $0.9 \mathrm{~m}$ apart; eight seeds were planted per meter, resulting in a population of 88,000 plants $\mathrm{ha}^{-1}$. In Experiment 2, the plots with sorghum consisted of eight rows spaced $0.45 \mathrm{~m}$ apart; 17 seeds were planted per meter, resulting in a population of 377,000 plants $\mathrm{ha}^{-1}$. Brachiaria brizantha Hochst Stapf was planted together with the corn and sorghum; $B$. brizantha seeds were mixed with the soil fertilizer at sowing to contribute to the formation of the straw cover. The grain corn and silage sorghum were harvested in March 2013 and
2014, maintaining the area fallow for the three following months.

The autumn-winter crops consisted of common bean in Experiment 1 and sweet corn in Experiment 2, both planted in June, in 2012 and 2013. In Experiment 1, the common bean plots consisted of eight 4-meter rows spaced $0.45 \mathrm{~m}$ apart; 12.5 seeds were planted per meter, resulting in a population of 277,000 plants $\mathrm{ha}^{-1}$. In Experiment 2, the sweet corn plots consisted of four rows spaced $0.9 \mathrm{~m}$ apart; 8 seeds were planted per meter, resulting in a population of 88,000 plants $\mathrm{ha}^{-1}$. The common bean and sweet corn were harvested in August and September of 2013 and 2014.

The experiments were irrigated using a conventional sprinkler system, with emitters spaced $12 \mathrm{~m}$ apart. In the spring-summer seasons, irrigation was supplemental due to the rainy period in the region. In the autumn-winter season, the irrigation was carried out with variable watering intervals; the soil moisture was monitored through watermark sensors installed at $0.15 \mathrm{~m}$ depth to determine the irrigation time, and at $0.30 \mathrm{~m}$ depth to monitor the water depth applied.

The soil physical-hydrological properties were characterized before the implementation of the crops in both tillage systems. The results were used to determine the critical tension for the irrigation management in both systems, which was $20 \mathrm{kPa}$. This value is a little lower than that calculated for the CTS and NTS treatments in this study, for safety reasons. The irrigation water depths used were calculated to apply the quantity of water needed to raise the soil moisture to the field capacity.

Grain corn crops were evaluated for one hundred grain weight, ear yield without husk, and grain yield. The ears without husks and grains from 
the evaluation area of each plot were weighed and the values were transformed into $\mathrm{Mg} \mathrm{ha}{ }^{-1}$. After the harvest, three samples of one hundred grains were randomly collected, discarding broken grains, to obtain the one hundred grain weight. The values of one hundred grain weight and grain yield were corrected to $13 \%$ moisture using Equation 1:

$$
\mathrm{FW}=\mathrm{IW}\left[\frac{100-\mathrm{IM}}{100-\mathrm{FM}}\right]
$$

where FW is the sample corrected final weight $(\mathrm{g})$, IW is the sample initial weight $(\mathrm{g})$, IM is the sample initial moisture (\%), and FM is the final moisture, in this case, $13 \%$.

Common bean crops were evaluated for final stand, grain yield, and primary components (number of pods per plant, number of grains per pod, and mean one hundred grain weight). The number of pods per plant, number of grains per pod, and yield was estimated after the harvesting of all plants in the plot evaluation area. After the harvest, three samples of one hundred grains were randomly chosen, discarding broken grains, to obtain the one hundred grain weight. The number of grains per pod was estimated by dividing the total number of grains in the evaluation area by the total number of pods in the evaluation area; the total number of grains in the evaluation area was calculated using the values of one hundred grain weight and total grain weight of the evaluation area of each plot. The values of yield and one hundred grain weight were corrected to $13 \%$ moisture, using Equation (1).

Sorghum crops were evaluated for plant height, fresh matter yield, and dry matter yield. Subsamples were dried at $65{ }^{\circ} \mathrm{C}$ until constant weight and weighed before and after drying to obtaining the ratio between dry matter and fresh matter weights, which was used to calculate the dry matter yield, using Equation (2):

$$
\mathrm{DMY}=\left(\frac{\mathrm{SDW}}{\mathrm{SFW}}\right) \mathrm{FMY}
$$

where DMY is the dry matter yield $\left(\mathrm{Mg} \mathrm{ha}^{-1}\right)$, SDW is the sample dry weight $(\mathrm{g})$, SFW is the sample fresh weight $(\mathrm{g})$, and FMY is the fresh matter yield $\left(\mathrm{Mg} \mathrm{ha}^{-1}\right)$.

Sweet corn crops were evaluated for mean ear length, mean ear diameter, total ear yield without husk, commercial ear yield without husk, and percentage of commercial ears. The percentage of commercial ears was calculated by the ratio between commercial ear yield without husk, and total ear yield without husk. Commercial ears were those with lengths above $15 \mathrm{~cm}$ and diameters above $3 \mathrm{~cm}$, as used by Aguiar et al. (2012).
The irrigation water depths applied during the common bean and sweet corn crops in the autumnwinter seasons of 2013 and 2014 in both experiments were added to rainfall depths found during the crop cycles to evaluated the water consumption and use efficiency (WUE), in the CTS and NTS. Crops grown in the spring-summer seasons in both experiments were not evaluated for WUE, since these are rainy seasons in the region and determining the effective rainfall was unfeasible. The WUE was calculated by dividing the values of common bean grain yield and commercial ears $\left(\mathrm{kg} \mathrm{ha}^{-1}\right)$ by the water depth consumed ( $\mathrm{mm}$ ) during the crop cycle; the efficiency was determined in $\mathrm{kg} \mathrm{ha}^{-1} \mathrm{~mm}^{-1}$.

The data obtained were subjected to individual and joint analysis of variance by the $\mathrm{F}$ test at $5 \%$ significance level, considering the two crop years in each crop season. The homogeneity of residual variances was found by the maximum $\mathrm{F}$ test, considering homogeneous when the ratio between the highest and lowest residual mean square was lower than or equal to seven. In the case of significance $(p \leq 0.05)$, the means of the tillage systems and crop years were subjected to the F test.

\section{RESULTS AND DISCUSSION}

In Experiment 1, the joint analysis of variance referring to the grain corn crops grown in the springsummer seasons of 2012/2013 and 2013/2014 showed significant effects of tillage systems (TS) and crop year (YEAR) for grain yield (GY), and significant effects of the interaction $(\mathrm{TS} \times$ YEAR) for one hundred grain weight $(100 \mathrm{GW})$ and ear yield without husk (EYWH). The 100GW in the no-tillage system (NTS) was higher than in the conventional tillage system (CTS) in the second crop year (Table 1). This result denotes the superiority of NTS over CTS, different from the results reported by Farinelli and Lemos (2012), who found that $100 \mathrm{GW}$ of corn crops grown in the summer is not affected by the tillage system in subtropical climate conditions.

EYWH was also higher under NTS in the second year (Table 1). This result denotes a positive correlation between $100 \mathrm{GW}$ and EYWH, and is correlated to the best climate conditions of the second crop year, which presented milder temperatures and better rainfall distribution (Figure 1), which enabled a higher grain weight, resulting in a higher EYWH. The corn GY in the NTS reached a mean of $10.25 \mathrm{Mg} \mathrm{ha}^{-1}$, considering both crop years, which was $21.45 \%$ higher than that in the CTS (Table 1). Yu et al. (2016) evaluated the responses of corn crops to different tillage systems and found that the yield under NTS is higher than that under CTS. However, a higher corn yield under CTS when compared to NTS is common when the NTS is under implementation (GUAN et al., 2014). However, the 
corn yields found in the present study was higher than the Brazilian national mean corn yield in the summer season of 2020 , estimated in $6.07 \mathrm{Mg} \mathrm{ha}^{-1}$ even under CTS (CONAB, 2021).

Table 1. Mean one hundred grain weight $(100 \mathrm{GW})$, ear yield without husk (EYWH), and grain yield (GY) of corn crops grown in no-tillage (NTS) and conventional tillage (CTS) systems in the spring-summer seasons of 2012/2013 and 2013/2014. Nova Porteirinha, MG, Brazil.

\begin{tabular}{cccccccc}
\hline \multirow{2}{*}{ Systems } & \multicolumn{2}{c}{$100 \mathrm{GW}(\mathrm{g})$} & \multicolumn{2}{c}{ EYWH $\left(\mathrm{Mg} \mathrm{ha}^{-1}\right)$} & \multicolumn{3}{c}{$\mathrm{GY}\left(\mathrm{Mg} \mathrm{ha}^{-1}\right)$} \\
\cline { 2 - 8 } & $2012 / 2013$ & $2013 / 2014$ & $2012 / 2013$ & $2013 / 2014$ & $2012 / 2013$ & $2013 / 2014$ & Mean \\
\hline CTS & $30.13 \mathrm{Aa}$ & $30.20 \mathrm{Ba}$ & $8.58 \mathrm{Ab}$ & $10.83 \mathrm{Ba}$ & 7.38 & 9.50 & $8.44 \mathrm{~B}$ \\
NTS & $30.65 \mathrm{Ab}$ & $34.94 \mathrm{Aa}$ & $9.61 \mathrm{Ab}$ & $14.10 \mathrm{Aa}$ & 8.33 & 12.16 & $10.25 \mathrm{~A}$ \\
\hline Mean & 30.39 & 32.57 & 9.09 & 12.46 & $7.86 \mathrm{~b}$ & $10.83 \mathrm{a}$ & - \\
\hline
\end{tabular}

Means followed by same uppercase letter in the columns, comparing tillage systems, and lowercase letters in the rows, comparing crop years, are not different from each other by the $\mathrm{F}$ test at $5 \%$ significance level.

The highest 100GW, EYWH, and GY of corn under NTS found in the present work was probably due to the higher organic matter accumulation in this system, when compared to CTS. Organic matter favors soil physical conditions, increases aeration, water retention and storage, improves chemical properties, supplies nutrients, increases cation exchange capacity, and promotes the soil microbiota activity (FIGUEIREDO; RAMOS; TOSTES, 2008). Güereña et al. (2016) evaluated poor and degraded soils in western Kenya and found that the combination of mineral soil fertilizers and organic matter is an important strategy to maintain corn yield in the long-term. Sales et al. (2017) studied the same experimental area of the present work and found that corn crops under NTS present higher carbon and nitrogen contents, and organic matter fractions in the soil surface layer.

Corn grain yield was higher in the 2013/2014 crop year (Table 1). This result may be also correlated to the climate conditions of each crop year, since in the spring-summer season of 2013/2014, the rainfall depth was $94.90 \mathrm{~mm}$ higher and more well distributed, and temperatures were slightly lower than those in 2012/2013 (Figure 1), favoring the crop development. According to Landau, Magalhães, and Guimarães (2020), high night-time temperatures $\left(>30{ }^{\circ} \mathrm{C}\right)$ for long periods decrease corn grain yields due to consumption of metabolites developed during the day. The results of the present work are consistent with those of $\mathrm{Yu}$ et al. (2016), who conducted a similar study and attributed the variation of corn yield in three crop years to climate factors, which affect photosynthesis rate and, consequently, the plant growth and production stability.

In Experiment 1, the analysis of variance referring to common bean grown in the autumnwinter seasons of 2013 and 2014, in succession to grain corn, showed significant effects of the sources of variation (TS and YEAR) for number of grains per pod (NGP), and significant effects of the interaction TS $\times$ YEAR for number of pods per plant (NPP) and one hundred grain weight (100GW).

The NTS resulted in a higher NPP in 2013; however, no significant difference $(\mathrm{p} \leq 0.05)$ between tillage systems was found in 2014. Considering the effects of the crop years within each tillage system, NTS showed a higher NPP in 2013 than in 2014 (Table 2). NGP was higher in CTS than in NTS, and higher in 2013 than in 2014 (Table 2); however, these differences were small. Farinelli et al. (2006) evaluated yields common bean crops grown under different rates of nitrogen and found no difference between CTS and NTS for NPP and NGP.

Table 2. Mean number of pods per plant (NPP), number of grains per pod (NGP), one hundred grain weight (100GW), and grain yield (GY) of common bean crops grown in no-tillage (NTS) and conventional tillage (CTS) systems in the springsummer seasons of 2013 and 2014. Nova Porteirinha, MG, Brazil.

\begin{tabular}{|c|c|c|c|c|c|c|c|c|}
\hline \multirow{2}{*}{ Systems } & \multicolumn{2}{|c|}{ NPP } & \multicolumn{3}{|c|}{ NGP } & \multicolumn{2}{|c|}{$100 \mathrm{GW}(\mathrm{g})$} & \multirow{2}{*}{$\frac{\mathrm{GY}\left(\mathrm{kg} \mathrm{ha}^{-1}\right)}{\text { Mean }}$} \\
\hline & 2013 & 2014 & 2013 & 2014 & Mean & 2013 & 2014 & \\
\hline CTS & $14.80 \mathrm{Ba}$ & $15.87 \mathrm{Aa}$ & 4.90 & 4.86 & $4.88 \mathrm{~A}$ & $27.42 \mathrm{Aa}$ & $27.98 \mathrm{Ba}$ & $3520.33 \mathrm{~A}$ \\
\hline NTS & $17.62 \mathrm{Aa}$ & $13.21 \mathrm{Ab}$ & 4.83 & 4.29 & $4.55 \mathrm{~B}$ & $26.68 \mathrm{Ab}$ & $29.61 \mathrm{Aa}$ & $3759.81 \mathrm{~A}$ \\
\hline Mean & 16.21 & 14.54 & $4.87 \mathrm{a}$ & $4.57 \mathrm{~b}$ & - & 27.05 & 28.84 & 3640.07 \\
\hline
\end{tabular}

Means followed by same uppercase letter in the columns, comparing tillage systems, and lowercase letters in the rows, comparing crop years, are not different from each other by the $\mathrm{F}$ test at $5 \%$ significance level.

Rev. Caatinga, Mossoró, v. 35, n. 1, p. 33 - 43, jan. - mar., 2022 
The one hundred grain weight $(100 \mathrm{GW})$ of common bean crops were different between tillage systems only in 2014, with NTS presenting higher means than the CTS (Table 2). However, the values of all evaluations were consistent with the commercial standards for common beans of the Carioca group. Leite et al. (2013) reported similar values, but found no significant differences for one hundred grain weight between CTS and NTS.

The common bean grain yield (GY) was not affected by the evaluated treatments. Despite some differences were found between tillage systems and crop years for yield components (NPP, NGP and $100 \mathrm{GW})$, these differences were mostly small and were not enough to generate significant difference in GY. Effects of NTS and CTS on common bean yield are divergent in the literature. Rocha et al. (2011) evaluate the application of different rates of molybdic fertilizer in NTS and CTS and found better results for the NTS, whereas Leite et al. (2013) found no difference for grain yield between these systems. Farinelli et al. (2006), evaluated common bean yield in two crop seasons and found similar yields between CTS and NTS in the first and higher for NTS in the second crop season. The yield found in the present work was higher than those reported in other studies (FARINELLI et al., 2006; BIZARI et al., 2009; ROCHA et al., 2011; LEITE et al., 2013) and very higher than the Brazilian mean national yield for common bean crops of the Cores commercial group grown in the autumn-winter season of 2020, estimated in $1636 \mathrm{~kg} \mathrm{ha}^{-1}$ (CONAB, 2021).

The crop yields found in the grain corncommon bean rotation were, in general, satisfactory for the northern region of Minas Gerais in both tillage systems evaluated. Moreover, the benefits of NTS reflected in a higher grain yield for the corn crops. However, despite increasing values of some production components for the common bean crops, the NTS did not generate significant effect to increase grain yield. Mingotte et al. (2014) evaluated crop systems before common bean crops under NTS and found that the yield of summer corn grown intercropped with Urochloa ruziziensis was similar to that of corn grown alone, $7,000 \mathrm{~kg} \mathrm{ha}^{-1}$. In addition, when growing common bean in the winter, in succession to intercropped corn, they found a mean yield of $3,000 \mathrm{~kg} \mathrm{ha}^{-1}$. According to Carmeis Filho et al. (2014), corn intercropped with Urochloa ruziziensis improves the straw cover formation for the NTS, efficiently covering the soil surface; thus, it is adequate for the common bean crop in succession.

In the present work, the NTS increased the yield of corn crops grown in the spring-summer seasons, but not the yield of common bean crops grown in the autumn-winter season. It may also be correlated to the climate conditions in each crop season, since the temperatures in the spring-summer seasons were higher than those in the autumn-winter season (Figure 1). It may have caused higher soil water losses by evaporation in the spring-summer seasons, mainly in the CTS, in which there was absence of soil protection by cover plants (MOREIRA et al., 2011; MURGA-ORRILLO et al., 2016). Therefore, the presence of soil cover in the NTS and its action on soil protection against solar radiation and winds (SILVA et al., 2015) may have lowered losses by evaporation, and been the factor that caused the difference between NTS and CTS in the spring-summer seasons.

In Experiment 2, the joint analysis of variance referring to the sorghum crop in the spring-summer seasons of 2012/2013 and 2013/2014 showed significant effect of the sources of variation (TS and YEAR) for plant height $(\mathrm{PH})$ and fresh matter yield (FMY). The interaction TS $\times$ YEAR was significant only for dry matter yield (DMY).

Considering the tillage systems, NTS promoted a higher $\mathrm{PH}$ when compared to CTS (Table 3). The PH found were similar to that reported by Albuquerque et al. (2013), who evaluated the forage sorghum variety BRS Ponta Negra under CTS in the semiarid region of the state of Minas Gerais, Brazil, and found a mean plant height of $2.26 \mathrm{~m}$.

Table 3. Mean plant height (PH), fresh matter yield (FMY) and dry matter yield (DMY) of forage sorghum plants grown in no-tillage (NTS) and conventional tillage (CTS) systems in the spring-summer seasons of 2012/2013 and 2013/2014. Nova Porteirinha, MG, Brazil.

\begin{tabular}{ccccccccc}
\hline \multirow{2}{*}{ Systems } & \multicolumn{3}{c}{ PH $(\mathrm{m})$} & \multicolumn{3}{c}{ FMY $\left(\mathrm{Mg} \mathrm{ha}{ }^{-1}\right)$} & \multicolumn{2}{c}{ DMY $\left(\mathrm{Mg} \mathrm{ha}{ }^{-1}\right)$} \\
\cline { 2 - 9 } & $2012 / 2013$ & $2013 / 2014$ & Mean & $2012 / 2013$ & $2013 / 2014$ & Mean & $2012 / 2013$ & $2013 / 2014$ \\
\hline CTS & 2.10 & 1.97 & $2.03 \mathrm{~B}$ & 114.45 & 72.62 & $93.53 \mathrm{~B}$ & $25.63 \mathrm{Aa}$ & $20.01 \mathrm{Bb}$ \\
NTS & 2.23 & 2.10 & $2.17 \mathrm{~A}$ & 138.67 & 122.55 & $130.61 \mathrm{~A}$ & $29.28 \mathrm{Ab}$ & $36.87 \mathrm{Aa}$ \\
\hline Mean & $2.16 \mathrm{a}$ & $2.04 \mathrm{~b}$ & - & $126.56 \mathrm{a}$ & $97.58 \mathrm{~b}$ & - & 27.46 & 28.44 \\
\hline
\end{tabular}

Means followed by same uppercase letter in the columns, comparing tillage systems, and lowercase letters in the rows, comparing crop years, are not different from each other by the $\mathrm{F}$ test at $5 \%$ significance level. 
The FMY was higher in the 2012/2013 crop season, which may be due to the higher $\mathrm{PH}$ found in this crop season. FMY was, on average, 39.65\% higher in the NTS when compared to the CTS. DMY presented difference between tillage systems only in $2013 / 2014$, with $84.26 \%$ higher DMY in the NTS (Table 3). Silva et al. (2015) found higher FMY and DMY for NTS when compared to CTS when evaluating silage corn production under the effect of dry spell, and that this result was probably correlated to improvements in soil chemical characteristics promoted by the NTS, such as increases in organic matter and nitrogen contents in the soil surface layers (GUARESCHI; PEREIRA; PERIN, 2014; SALES et al., 2017).

In general, the higher growth of sorghum plants in the NTS, shown by the $\mathrm{PH}$, affected positively the forage sorghum production, since FMY and DMY were also higher in the NTS. The DMY found were very higher than those reported by Albuquerque et al. (2013) for the variety BRS Ponta Negra grown under CTS, in Nova Porteirinha, MG, Brazil, which was $9.59 \mathrm{Mg} \mathrm{ha}^{-1}$. The difference between these results can be explained by the lower population used in that study $\left(120,000\right.$ plants $\left.\mathrm{ha}^{-1}\right)$ when compared to that used in the present study $\left(377,000\right.$ plants ha $\left.{ }^{-1}\right)$.

In Experiment 2, the analysis of variance referring to sweet corn grown in the autumn-winter seasons of 2013 and 2014 in succession to sorghum showed significant effect $(p \leq 0.05)$ of the source of variation TS for ear length (EL), total ear yield without husk (TEYWH), commercial ear yield without husk (CEYWH) and percentage of commercial ears (PCE). Ear diameter (ED) was significantly affected $(\mathrm{p} \leq 0.05)$ only by the source of variation YEAR. However, the difference between the years was small, with means of 4.54 and $4.61 \mathrm{~cm}$ in 2013 and 2014, respectively.

The ED found were similar to those reported by Aguiar et al. (2012) for a CTS; they found a mean ED of $4.60 \mathrm{~cm}$, considering 22 sweet corn genotypes. The higher EL was found in the NTS (Table 4), however, the ears reached diameter and length means consistent with the commercial ear classification in both tillage systems, i.e., ED higher than $3 \mathrm{~cm}$ and EL higher than $15 \mathrm{~cm}$ (AGUIAR et al., 2012).

Table 4. Mean ear diameter (ED), ear length (EL), total ear yield without husk (TEYWH), commercial ear yield without husk (CEYWH), and percentage of commercial ears (PCE) of sweet corn crops grown in no-tillage (NTS) and conventional tillage (CTS) systems in the autumn-winter seasons of 2013 and 2014. Nova Porteirinha, MG, Brazil.

\begin{tabular}{ccccc}
\hline Systems & EL $(\mathrm{cm})$ & TEYWH $\left(\mathrm{Mg} \mathrm{ha}^{-1}\right)$ & CEYWH $\left(\mathrm{Mg} \mathrm{ha}^{-1}\right)$ & PCE $(\%)$ \\
\hline CTS & $18.48 \mathrm{~B}$ & $13.93 \mathrm{~B}$ & $11.56 \mathrm{~B}$ & $82.48 \mathrm{~B}$ \\
NTS & $19.92 \mathrm{~A}$ & $15.60 \mathrm{~A}$ & $14.08 \mathrm{~A}$ & $90.42 \mathrm{~A}$ \\
\hline
\end{tabular}

Means followed by the same letter in the columns, comparing the tillage systems, are not different from each other by the $\mathrm{F}$ test at 5\% significance level. Means of 2013 and 2014.

The higher ear growth in the NTS, shown by the EL (Table 4), may be correlated to the soil cover in this system, which favors soil water storage and availability (FIGUEIREDO; RAMOS; TOSTES, 2008). In addition, it is an important reserve of nutrients, that are gradually released to the soil surface layer through the decomposition of cover plants that absorbed them from the soil subsurface layers (DUDA et al., 2003). Mendonça et al. (2015), found that the straw cover from grass intercropped with corn in rotation with soybean in no-tillage system increases the cycling and promotes a gradual release of macronutrients to the succeeding crop. In addition, they found a potassium $(\mathrm{K})$ accumulation of $150 \mathrm{~kg} \mathrm{ha}^{-1}$ in the straw cover, with its complete release in the following crop (soybean) at 90 days after the desiccation of the grass species. Silva (2013) also verified higher EL for NTS $(16.98 \mathrm{~cm})$ when compared to CTS $(15.58 \mathrm{~cm})$.

The NTS resulted in a $11.99 \%$ higher TEYWH than the CTS (Table 4). Similarly, Silva (2013) found higher total ear production for the NTS, but they evaluated ears production with straw.
The CEYWH in the NTS was $21.80 \%$ higher than that in the CTS. Thus, under the conditions of the present study, the use of NTS is more appropriate for sweet corn crops due to the higher commercial ear production obtained in this system when compared to the CTS.

The highest PCE was found for the NTS, which was 7.94\% higher than that found in the CTS. A high PCE is desirable for sweet corn crops, since it indicates a better production, and most ears produced can meet the commercial standards to be marketed. The PCE found were similar those reported by Favarato et al. (2016) in a similar study; they found PCE varying from $82.53 \%$ to $90.88 \%$, but considering ED above $4 \mathrm{~cm}$ as the commercial diameter.

The highest CEYWH found in the NTS can be correlated to the higher organic matter contents in the soil surface layers in this system, when compared to the CTS (MELO et al., 2016). Oliveira et al. (2017) found higher sweet corn yields in the NTS, when compared to the CTS and minimum cultivation (MC) and attributed these results to the higher

Rev. Caatinga, Mossoró, v. 35, n. 1, p. 33 - 43, jan. - mar., 2022 
organic matter contents and water storage in the soil profile in the conservationist systems (MC and NTS), which probably decreased stress conditions during the ear formation and development stages.

Therefore, the sorghum-sweet corn rotation provided better agronomic performance and higher yields in the NTS, for the sorghum grown in the spring-summer seasons and for the sweet corn grown in the autumn-winter season. Sales et al. (2016) found that including these grass species (corn and sorghum) under NTS in semiarid regions results in high straw productions ( $\left.>16 \mathrm{Mg} \mathrm{ha}^{-1}\right)$ and better soil physical structure, and increases soil organic carbon contents. Despite it is an unusual crop rotation composed of two grass species, the sorghum-sweet corn rotation under NTS presented satisfactory yield results under the semiarid conditions evaluated, mainly due to the straw production and soil cover, even considering only two crop seasons.

Regarding the water use efficiency (WUE) in the autumn-winter seasons, the joint analyses of variance showed that both experiments presented significant effect $(p \leq 0.05)$ of the the sources of variation (TS and YEAR). WUE refers to the total crop yield divided by the quantity of water used; thus, higher efficiencies can be achieved by using technologies that increase yield and strategies that make possible to decrease water consumption (TEÓFILO et al., 2012).

In both the experiments, crops grown in the autumn-winter seasons under NTS presented lower water consumption. Common bean crops presented water consumptions in 2013 of 495.06 and 301.19 $\mathrm{mm}$ in the CTS and NTS, respectively, which represents a water saving of $39.16 \%$ for the NTS when compared to the CTS. In 2014, water consumption in the CTS and NTS were 348.64 and $225.72 \mathrm{~mm}$, respectively, representing a water saving of $35.26 \%$ in the NTS. Economy of water in common bean crops grown in NTS have been reported in the literature (BIZARI et al., 2009), and can be correlated to the higher water retention and availability in this system when compared to CTS, mainly in the soil surface layers (DALMAGO et al., 2009).

The WUE of common bean crops in the 2014 was higher than that in the 2013 crop season (Table 5). This result may be correlated to the climate conditions in the autumn-winter of 2014, which presented milder temperatures than those in the autumn-winter of 2013 (Figure 1), decreasing the soil water evaporation, crop water consumption and, consequently, increasing the crop WUE in 2014. Common bean crops grown under NTS presented higher WUE, producing $14.35 \mathrm{~kg} \mathrm{ha}^{-1}$ of beans per millimeter of water. This value is $66.86 \%$ higher than that found in the CTS (Table 5). Bizari et al. (2009) also found higher WUE for common bean crops grown under NTS $\left(10.46 \mathrm{~kg} \mathrm{ha}^{-1} \mathrm{~mm}^{-1}\right)$ when compared to CTS $\left(5.72 \mathrm{~kg} \mathrm{ha}^{-1} \mathrm{~mm}^{-1}\right)$, representing an increase of $45 \%$. Cunha et al. (2013) evaluated common bean crops under NTS with different irrigation managements and found a mean WUE of $8.86 \mathrm{~kg} \mathrm{ha}^{-1} \mathrm{~mm}^{-1}$.

Table 5. Water use efficiency (WUE) in the common bean and sweet corn crops grown in no-tillage (NTS) and conventional tillage (CTS) systems in the autumn-winter seasons of 2013 and 2014. Nova Porteirinha, MG, Brazil.

\begin{tabular}{ccccccc}
\hline & \multicolumn{3}{c}{ Common bean } & \multicolumn{3}{c}{ Sweet corn } \\
\cline { 2 - 7 } Systems & \multicolumn{3}{c}{ WUE $\left(\mathrm{kg} \mathrm{ha}^{-1} \mathrm{~mm}^{-1}\right)$} & \multicolumn{3}{c}{ WUE $\left(\mathrm{kg} \mathrm{ha}^{-1} \mathrm{~mm}^{-1}\right)$} \\
\cline { 2 - 7 } & 2013 & 2014 & Mean & 2013 & 2014 & Mean \\
\cline { 2 - 7 } CTS & 7.14 & 10.06 & $8.60 \mathrm{~B}$ & 20.95 & 31.33 & $26.14 \mathrm{~B}$ \\
NTS & 13.69 & 15.00 & $14.35 \mathrm{~A}$ & 40.06 & 56.23 & $48.14 \mathrm{~A}$ \\
\hline Mean & $10.42 \mathrm{~b}$ & $12.53 \mathrm{a}$ & - & $30.50 \mathrm{~b}$ & $43.78 \mathrm{a}$ & - \\
\hline
\end{tabular}

Means followed by same uppercase letter in the columns, comparing tillage systems, and lowercase letters in the rows, comparing crop years, are not different from each other by the $\mathrm{F}$ test at $5 \%$ significance level.

The total water depths used for the sweet corn crop in 2013 were 530.18 and $337.02 \mathrm{~mm}$ for the CTS and NTS, respectively. It corresponds to a water saving of $36.43 \%$ in the NTS. In 2014, the water depths used for the CTS and NTS were 383.76 and $260.84 \mathrm{~mm}$, respectively, corresponding to a water saving of $32.03 \%$ in the NTS. Silva (2013) evaluated sweet corn under the effect of dry spell and found the lowest water consumption in the NTS (305.14 to $599.07 \mathrm{~mm}$ ), which provided a mean water saving of
$4.09 \%$ when compared to the CTS (323.44 a $619.13 \mathrm{~mm}$ ).

The WUE calculated based on the CEYWH in the 2014 was higher than that found in the 2013 crop season (Table 5). This result may also be correlated to the milder climate conditions in the autumn-winter season of 2014 (Figure 1). The sweet corn grown under NTS presented higher WUE, producing $48.14 \mathrm{~kg} \mathrm{ha}^{-1}$ of commercial ears per millimeter of water; it was $84.16 \%$ higher than that 
found in the CTS. Moreover, these higher WUE found for the NTS were due to the higher CEYWH (Table 4) and lower water consumption in this system. Nascimento et al. (2015) evaluated sweet corn crops grown under under CTS with different irrigation water depths and found a maximum WUE of $2.48 \mathrm{~kg} \mathrm{~m}^{-3}$, equivalent to $24.85 \mathrm{~kg} \mathrm{ha}^{-1} \mathrm{~mm}^{-1}$, for the water depth of $340.57 \mathrm{~mm}$, considering ears without husks.

The economy of water in the common bean and sweet corn crops under NTS may be correlated to the soil protection by the straw cover in this system, which reduce losses by evaporation and surface runoff (MOREIRA et al., 2011; PANACHUKI et al., 2011; SILVA, et al., 2015; MURGA-ORRILO et al., 2016). Pereira et al. (2015) found that the use of $12 \mathrm{Mg} \mathrm{ha}^{-1}$ of straw covering the soil provides a better water use and yield (3030 kg ha ${ }^{-1}$ ) for irrigated common bean crops

The higher WUE found in the NTS can also be correlated to the lower competition for water between the crop and weeds, enabled by this system. Teófilo et al. (2012) evaluated the effect of weeds on melon crops under CTS and NTS and found $86.7 \%$ and $61 \%$ lower populational density and accumulated dry weight of weeds, respectively, for the NTS.

Murga-Orrillo et al. (2016) evaluated the effect of soil cover on grain corn production and estimated that the water consumption in the soil with no straw cover was $16.17 \%$ higher than that in the covered soil. Similarly, Moreira et al. (2011) found higher WUE for production of commercial ears of sweet corn by adding straw cover (Brachiaria decumbens), with WUE of 32 and $48.70 \mathrm{~kg} \mathrm{ha}^{-1} \mathrm{~mm}^{-}$ 1 for the soil with no cover and for the soil with $100 \%$ covered surface, respectively.

\section{CONCLUSIONS}

The use of grain corn-common bean rotation under no-tillage system (NTS) increases yield of corn crops grown in the spring-summer seasons in $21.45 \%$, when compared to the conventional tillage system (CTS). Common bean crops grown in the autumn-winter season show no difference in grain yield between these tillage systems.

The use of sorghum-sweet corn rotation under NTS results in higher plant heights, and increases of 39.65 and $84.26 \%$, respectively, for fresh matter and dry matter yields of sorghum crops grown in the spring-summer seasons.

Sweet corn crops grown in the autumn-winter seasons present higher ear lengths and percentages of commercial ears, and increases of $11.99 \%$ and $21.80 \%$, respectively, in total ear yield and commercial ears without husks when the plants grown under NTS.

The corn-common bean and sorghum-sweet corn rotations present higher WUE in the autumnwinter seasons when using the NTS. Common bean and sweet corn crops grown under NTS present, respectively, $66.86 \%$ and $84.16 \%$ higher WUE than those under CTS.

\section{ACKNOWLEDGEMENTS}

The authors thank the Brazilian Coordination for the Improvement of Higher Education Personnel (CAPES), the Brazilian Agricultural Research Corporation (EMBRAPA Maize and Sorghum), and the State University of Montes Claros (UNIMONTES) for granting scholarships and supporting this research project.

This study was funded in part by the Coordination for the Improvement of Higher Education Personnel (CAPES) - Financial Code 001.

\section{REFERENCES}

AGUIAR, C. B. N. et al. Desempenho agronômico de híbridos de milho verde em função da adubação nitrogenada de cobertura. Revista de Ciências Agrárias, 55: 11-16, 2012.

ALBUQUERQUE, C. J. B. et al. Características agronômicas e bromatológicas dos componentes vegetativos de genótipos de sorgo forrageiro em Minas Gerais. Revista Brasileira de Milho e Sorgo, 12: 164-182, 2013

ALMEIDA, D. O. Fauna epiedáfica e atributos microbiologicos de solos sob sistemas de manejo no subtrópico brasileiro. 2012. 95 f. Tese (Doutorado em Ciência do Solo) - Universidade Federal do Rio Grande do Sul, Porto Alegre, 2012.

ALMEIDA, J. B. et al. O sensoriamento remoto aplicado ao estudo da desertificação na região semiárida do Norte de Minas Gerais. Revista Brasileira de Geomática, 2: 41-49, 2014.

ALMEIDA, V. et al. Comparação da viabilidade econômica da agricultura irrigada por pivô central em sistemas de plantios convencional e direto com soja, milho e tomate industrial. Global Science And Technology, 11: 256-273, 2018.

BIZARI, D. R. et al. Consumo de água e produção de grãos do feijoeiro irrigado em sistemas plantio direto e convencional. Ciência Rural, 39: 20732079, 2009.

CARMEIS FILHO, A. C. A. et al. Adubação nitrogenada no feijoeiro após a palhada de milho e braquiária no plantio direto. Revista Caatinga, 27: 
$66-75,2014$.

CONAB - Companhia Nacional de Abastecimento. Observatório Agrícola: acompanhamento da safra brasileira de grãos. Safra 2020/21. Sexto levantamento, v. 8, n. 6. Brasília, 2020/21. Disponível em: <https://www.conab.gov.br/infoagro/safras/graos>. Acesso em: 01 abr. 2021.

CUNHA, P. C. R. da et al. Manejo da irrigação no feijoeiro cultivado em plantio direto. Revista Brasileira de Engenharia Agrícola e Ambiental, 17: 735-742, 2013.

DALMAGO, G. A. et al. Retenção e disponibilidade de água às plantas, em solo sob plantio direto e preparo convencional. Revista Brasileira de Engenharia Agrícola e Ambiental, 13: 855-864, 2009.

DUDA, G. P. et al. Perennial herbaceous legumes as live soil mulches and their effects on $\mathrm{C}, \mathrm{N}$ and $\mathrm{P}$ of the microbial biomass. Scientia Agricola, 60: 139$147,2003$.

FARINELLI, R. et al. Adubação nitrogenada de cobertura no feijoeiro, em plantio direto e convencional. Pesquisa Agropecuária Brasileira, 41: 307-312, 2006.

FARINELLI, R.; LEMOS, L. B. Nitrogênio em cobertura na cultura do milho em preparo convencional e plantio direto consolidados. Pesquisa Agropecuária Tropical, 42: 63-70, 2012.

FAVARATO, L. F. et al. Crescimento e produtividade do milho-verde sobre diferentes coberturas de solo no sistema plantio direto orgânico. Bragantia, 75: 497-506, 2016.

FIGUEIREDO, C. C.; RAMOS, M. L. G.; TOSTES, $\mathrm{R}$. Propriedades físicas e matéria orgânica de um Latossolo Vermelho sob sistemas de manejo e cerrado nativo. Bioscience Journal, 24: 24-30, 2008.

GILLES, L. et al. Perdas de água, solo, matéria orgânica e nutriente por erosão hídrica na cultura do milho implantada em área de campo nativo, influenciadas por métodos de preparo do solo e tipos de adubação. Revista Brasileira de Ciência do Solo, 33: 1427-1440, 2009.

GUAN, D. et al. Tillage practices affect biomass and grain yield through regulating root growth, rootbleeding sap and nutrients uptake in summer maize.

Field Crops Research, 157: 89-97, 2014.

GUARESCHI, R. F.; PEREIRA, M. G.; PERIN, A. Carbono, nitrogênio e abundância natural de $\delta 13 \mathrm{C} E$ $\delta 15 \mathrm{~N}$ em uma cronossequência de agricultura sob plantio direto no cerrado goiano. Revista Brasileira de Ciência do Solo, 38: 1135-1142, 2014.

GÜEREÑA, D. T. et al. Maize productivity dynamics in response to mineral nutrient additions and legacy organic soil inputs of contrasting quality. Field Crops Research, 188: 113-120, 2016.

INMET - Instituto Nacional de Meteorologia. Banco de Dados Meteorológicos para Ensino e Pesquisa. Disponível em: <https://bdmep.inmet.gov.br/>. Acesso em: 17 nov. 2016.

LANDAU, E. C.; MAGAlHÃES, P. C.; GUIMARÃES, D. P. Árvore do Conhecimento (Milho): Relações com o clima. Disponível em: < https://www.agencia.cnptia.embrapa.br/gestor/milho/ arvore/CONTAG01_17_168200511157.html>. Acesso em: 26 jun. $\overline{2} 02 \overline{0}$.

LEITE, D. M. et al. Desempenho da cultura do feijão em função de diferentes sistemas de cultivo. Engenharia na Agricultura, 21: 539-546, 2013.

MARASCA, I. et al. Propriedades físicas de um Nitossolo Vermelho em função dos sistemas de uso e manejo. Revista Brasileira de Engenharia Agrícola e Ambiental, 17: 1160-1166, 2013.

MELO, G. B. et al. Estoques e frações da matéria orgânica do solo sob os sistemas plantio direto e convencional de repolho. Pesquisa Agropecuária Brasileira, 51: 1511-1519, 2016.

MENDONÇA, V. Z. et al. Liberação de nutrientes da palhada de forrageiras consorciadas com milho e sucessão com soja. Revista Brasileira de Ciência do Solo, 39: 183-193, 2015.

MiNGOTTE, F. L. C. et al. Sistemas de cultivo antecessores e doses de nitrogênio em cobertura no feijoeiro em plantio direto. Bioscience Journal, 30: 696-706, 2014.

MOREIRA, J. A. A. et al. Eficiência de uso de água pela cultura do milho (Zea mays) em função da cobertura do solo pela palhada no sistema plantio direto. In: VII CONGRESSO BRASILEIRO DE AGROECOLOGIA, 2011, Fortaleza, CE. Anais... Fortaleza: Cadernos de Agroecologia, 2011, v. 6, p. $1-4$.

MURGA-ORRILLO, $H$. et al. Influência da cobertura morta na evapotranspiração, coeficiente de cultivo e eficiência de uso de água do milho cultivado em cerrado. Irriga, 21: 352-364, 2016.

NASCIMENTO, F. N. et al. Parâmetros fisiológicos e produtividade de espigas verdes de milho sob diferentes lâminas de irrigação. Revista Brasileira 
de Milho e Sorgo, 14: 167-181, 2015.

OLIVEIRA F. C. C. et al. Características químicas de um Argissolo e a produção de milho verde nos Tabuleiros Costeiros sergipanos. Agrária, 12: 354360, 2017.

PANACHUKI, E. et al. Perdas de solo e de água e infiltração de água em Latossolo Vermelho sob sistemas de manejo. Revista Brasileira de Ciência do Solo, 35: 1777-1785, 2011.

PEREIRA, F. F. S. et al. Retenção de água em níveis de cobertura morta no feijoeiro irrigado em sistema plantio direto. Irriga, 20: 557-569, 2015.

PUGLIESI, A. C. V. et al. Valoração econômica do efeito da erosão em sistemas de manejo do solo empregando o método custo de reposição. Bragantia, 70: 113-121, 2011.

ROCHA, P. R. R. et al. Adubação molíbdica na cultura do feijão nos sistemas de plantio direto e convencional. Revista Caatinga, 24: 9-17, 2011.

SALES, R. P. et al. Organic matter fractions of an irrigated oxisol under no-till and conventional tillage in the brazilian semi-arid region. Revista Caatinga, 30: 303-312, 2017.

SALES, R. P. et al. Qualidade física de um Latossolo sob plantio direto e preparo convencional no semiárido. Revista Ciência Agronômica, 47: 429438, 2016.

SANTOS, H. G. et al. Sistema brasileiro de classificação de solos. 3. ed. rev. e ampl. Brasília, DF: Embrapa, 2013. 353 p.

SILVA, F. A. Produção de milho para ensilagem e espigas verdes em função de períodos de veranico nos sistemas de plantio direto e convencional. 2013. 86 f. Tese (Doutorado em Fitotecnia: Área de Concentração em Agricultura Tropical) Universidade Federal Rural do Semi-Árido, Mossoró, 2013.

SILVA, F. A. et al. Milho para ensilagem cultivado nos sistemas de plantio direto e convencional sob efeito de veranico. Semina: Ciências Agrárias, 36: 327-340, 2015.

TEÓFILO, T. M. S. et al. Eficiência no uso da água e interferência de plantas daninhas no meloeiro cultivado nos sistemas de plantio direto e convencional. Planta Daninha, 30: 547-556, 2012. plantio direto. Revista Brasileira de Ciência do Solo, 38: 639-649, 2014.

YU, C. -L. et al. Responses of corn physiology and yield to six agricultural practices over three years in middle Tennessee. Scientific Reports, 6: 1-9, 2016.

TIECHER, T. et al. Contribuição das fontes de sedimentos em uma bacia hidrográfica agrícola sob 